\title{
The Coronavirus and The Employees: A Study from the Point of Human Resource Management
}

\author{
H.H.D.N.P. Opatha \\ Senior Professor \\ Faculty of Management Studies and Commerce, \\ University of Sri Jayewardenepura \\ opatha@sjp.ac.lk
}

\begin{abstract}
A highly felt need of knowing specifically the impact of Coronavirus disease on employees from the point of Human Resource Management exists. Hence a conceptual attempt was made to find answers for four specific research questions addressing the meaning of Coronavirus disease and its characteristics, its hazardousness, its impact on employees, and identification of employees who are at greater risk. These research questions were answered by adopting a desk research strategy. The study yielded that Coronavirus disease 2019 is a deadly infectious disease which is shortly called COVID-19. It is a plague that can spread from an infected person-to-person, and spreading occurs between people who are in close contact with one another (within about 6 feet); and via respiratory droplets produced when an infected person coughs or sneezes. It is believed that patients are at their most contagious when they are most symptomatic, and some spread might be possible before people show symptoms. It is so hazardous that it can infect any person of any age living in any place in the world and subsequently cripple proper functioning of organizations of all sizes in all industries in all countries in the world. It has a tremendous negative impact on employees, and 15 specific fears were identified. The resultant stress was labeled as Stress By Corona (SBC). Employees who are at greater risk are health care, security force and police personnel.
\end{abstract}

Key Words: Burnout, Coronavirus Disease, Employees, Fear, Human Resource Management, Stress 


\section{Introduction}

Employees are the life blood of any organization and there are no organizations which are employee-less. Employees are human resources which are unique when compared them with all other resources such as financial, physical, and intangible resources. All other resources make things possible but only human resources make things happen (Opatha, 2009). The essence of management is decision making and decisions are made only by employees in the organizations and such made decisions are implemented too only by employees. Creativity and innovation are the drivers of organizational development, nation development, and global development as well and those two drivers are possessed by human resources who are identified as human capital.

Human Resource Management (HRM) refers to the functional field of Business Administration or Organizational Management which is concerned with managing people at work (Opatha, $2019^{2}$ ) and people at work refer to employees. HRM refers to the policies, practices, and systems that influence employees' behaviour, attitudes, and performance (Noe, Hollenbeck, Gerhart and Wright, 2007). It is the efficient and effective utilization of human resources to achieve goals of an organization; it is about managing people at work, being the human side of Business Administration having policies, procedures, rules, and systems influencing employees of the organization (Opatha, 2009). HRM is the leadership and management of people within an organization using systems, methods, processes, and procedures that enable employees to achieve their own goals that in turn enhance the employee's positive contribution to the organization and its goals (Schwind, Das, Wagar, Fassina, and Bulmash, 2013). Being indeed a well-recognized academic discipline as well as a well -recognized business practice, HRM generally attempts to serve for the organization where it is practiced, employees working for it and society at large (Arulrajah and Opatha, 2016; Opatha, 2019).

One of the functions of HRM is health and safety management that refers to all the activities involved in protecting and promoting physical and mental health of the employees so that they can perform jobs efficiently and effectively (Opatha, 2009). Promoting workplace safety and health is a critical HRM activity and the benefits of a safe and healthy work environment include (1) more productivity owing to fewer lost workdays, (2) increased efficiency and quality from a more committed workforce, (3) reduced medical and insurance costs, (4) lower workers' compensation rates and direct payments because of fewer claims being filled, (5) greater flexibility and adaptability in the workforce as a result of increased participation and an increased sense of ownership, and (6) better selection ratios because of the enhanced image of the organization (Jackson and Schuler, 2003).

Since February 2020 a shocking disease called COVID-19 or Corona has been attacking the people in the entire world. By the time of writing this paper, total deaths were more than one hundred and eighty thousands. From the point of HRM, the latest challenge for business organizations is Coronavirus. As a matter of fact it is not incorrect to write here that Coronavirus is the most dangerous catastrophe we ever had. From the point of HRM this is 
the most serious health hazard that the organization has to cope with in managing its people at work.

There is a highly felt need of knowing specifically the impact of Coronavirus disease on employees from the point of HRM. In addition, an intellectual puzzle exists to investigate how the Coronavirus disease impacts employees in an organization. This paper is an attempt to explore and describe what Coronavirus disease means and what its nature is, and then its impact on employees and the employees who are at greater risks.

\section{Research Questions and Objective}

Following research questions were formulated so that a systematic attempt could be made to find answers:

1. What is Coronavirus disease? What are its characteristics?

2. Why is it so hazardous?

3. What is its impact on employees?

4. Who are the employees at greater risks?

This research paper has its objective to find answers for the above mentioned four specific research questions.

\section{Method}

This research paper is a study which gives a theoretical contribution to the existing body of knowledge in terms of a synthesized account of COVID-19 in the context of HRM. Originally identified 15 types of employee's fears owing to the disease give a new adding to the existing knowledge. In order to answer the four research questions systematically, a comprehensive literature survey was done by using the desk research strategy in addition to the logical beliefs and empirical observations.

\section{Corona and Its Characteristics}

According to the Website of the University of Kansas, COVID-19, short for "Coronavirus disease 2019," is the official name given by the World Health Organization to the disease caused by a newly identified coronavirus. The World Health Organization (WHO) defines that Coronavirus disease is an infectious disease caused by a newly discovered coronavirus, and the COVID-19 virus spreads primarily through droplets of saliva or discharge from the nose when an infected person coughs or sneezes. It is a disease that is identified as a pandemic as it can affect a very large number of human beings living in an area. It has the potential of spreading very quickly from one person to many people. According to Orsi and Santos (2010), a pandemic is an infection that can spread globally and affect large populations. As identified by Staples (2006), a pandemic is an unfolding global event that comes in waves that can sweep across the globe in a matter of weeks, and it may take three months to control it. A pandemic is different from threats associated with bombs or natural disasters such as fires, earthquakes and tsunamis because such threats and crises are over once the event has occurred (Holland, Sheehan, Donohue, Pyman, and Allen, 2012). These threats and 
crises may damage and destruct infrastructure and humans unlike a pandemic which destructs only humans and may destroy non-humans.

Coronavirus or COVID-19 is a plague that can spread from an infected person-to-person. Spreading occurs between people who are in close contact with one another (within about 6 feet); and via respiratory droplets produced when an infected person coughs or sneezes (these droplets can land in the mouths or noses of people who are nearby or possibly be inhaled into the lungs) according to the insight information given on the Website of the UC Davis Health Experts. Further the Website gives that currently it is believed patients are at their most contagious when they are most symptomatic, and some spread might be possible before people show symptoms.

According to the WHO, at this time, there are no specific vaccines or treatments for COVID19 though there are many ongoing clinical trials evaluating potential treatments. Furthermore the organization points out that most people infected with the COVID-19 virus will experience mild to moderate respiratory illness and recover without requiring special treatment. This disease can have a serious impact on people who are older and also people who are having medical problems like cardiovascular disease, diabetes, chronic respiratory disease, and cancer according to the WHO.

Symptoms of coronavirus can include runny nose, sore throat, headache, fever, cough and shortness of breath (UC Davis Health Experts). Zhou (2020, p. 34) edits:

"The novel coronavirus is newly emergent in humans. Therefore, the general population is susceptible because they lack immunity against it. 2019-nCoV can infect individuals with normal or compromised immunity. The amount of exposure to the virus also determines whether you get infected or not. If you are exposed to a large amount of virus, you may get sick even if your immune function is normal. For people with poor immune function, such as the elderly, pregnant women or people with liver or kidney dysfunction, the disease progresses relatively quickly and the symptoms are more severe."

The best way to prevent and slow down transmission is be well informed about the COVID19 virus disease, its causes and how it spreads (WHO). The WHO instructs that you must engage in actions such as washing your hands or using an alcohol based rub frequently and not touching your face, and practicing respiratory etiquette (for example, by coughing into a flexed elbow) for the purpose of protection of yourself and others from infection.

\section{Hazardousness of Corona}

It was experienced that a large number of people died within a short period of time in the world at the day of writing this paragraph of this article. The people who got inflected have been increasing day by day at the time of writing this paper. Refer to Table 1. The total of Coronavirus cases, deaths, and recovered were 2639772, 184280, and 722395 respectively. The country which had the highest impact was USA and the total of Coronavirus cases, deaths, and recovered were 849092,47681 , and 84050 respectively. Countries which had 
very high impact include Spain (number of deaths: 21717, Italy (25085), France (21340), Germany (5315), UK (18100), China (4632), Iran (5391), Turkey (2376), and Belgium (6262) according to worldometer. In Sri Lanka the status of the impact of Coronavirus is not so worse relatively, however, it is considerable to an extent that cannot be ignored. Refer to Table 2. Owing to prompt actions taken by the Sri Lankan Government it was so far possible to control the impact in terms of cases, deaths, and recovered.

\section{Table 1: Some Figures of the Status of Coronavirus Impact in the World}

\begin{tabular}{|l|r|}
\hline Coronavirus Cases & $2,639,722$ \\
\hline Deaths & 184,280 \\
\hline Recovered & 722,395 \\
\hline
\end{tabular}

Source: worldometer, Up to date 23/04/2020

Table 2: Some Figures of the Status of Coronavirus Impact in Sri Lanka

\begin{tabular}{|l|c|}
\hline Coronavirus Cases & 330 \\
\hline Deaths & 7 \\
\hline Recovered & 105 \\
\hline
\end{tabular}

Source: worldometer, Up to date 23/04/2020

As there are no specific vaccines or treatments for COVID-19, it is very dangerous. Indeed corona kills people and hence it is deadly. It is one of the deadliest diseases ever existed in the world. It can spread from an infected person to one or two or several or many persons. People of all ages can be inflected by Coronavirus (UC Davis Health Experts). In business affairs people have to interact with each other. In managing, superiors have to get things done through subordinates. It is inevitable that people at homes interact with each other and get together for various purposes. Humans are naturally social. Employees are a kind of humans who interact with each other formally and informally in order to achieve goals of organizations where they are working. The global nature of business travel has increased the likelihood of the spread of a deadly virus (Mathis and Jackson, 2011).

Zhou (2020, p. 34) edits:

"The dominant factor determining whether one gets infected or not is the chance of exposure. So, it cannot be simply concluded that better immunity will lower one's risk of being infected. Children have fewer chances of exposure and thus a lower probability of infection. However, at the same exposure, senior people, people with chronic diseases or compromised immunity are more likely to get infected."

Thus, Coronavirus disease is so hazardous that all the possible actions at individual level, organizational level, country level, and global level as well have to be made in order to save humans. 
Generally in an organization, hazards which exist include occupational accidents, occupational diseases, law quality of work life, and occupational stress (Schuler and Youngblood, 1986; Opatha, 2009). Jackson, Schuler, and Verner (2012); Mathis and Jackson, 2011) mention three types of workplace safety hazards such as occupational accidents, occupational injuries, and workplace violence. Also they mention four workplace hazards to health of the employees such as occupational illnesses, hazards to mental health, workplace stressors, and job burnout. It is possible to mention that coronavirus is more hazardous than the generally identified workplace hazards. As a pandemic, Coronavirus is more dangerous than disasters such as earthquakes, hurricanes, major snowstorms, flooding, forest fires, and tornados because of the possible quick deadly attack to a large number of people not only in one country but also in the entire world.

The costs to the organization are very high when its high performing employees become infected. If an outstanding employee dies owing to Coronavirous, the costs of death are uncountable. The loss is tremendous.

When an employee is identified as a Coronavirus patient by the relevant medical authority, the entire unit, department, or the organization will have to be shut down. Duration of shutting down may be three weeks or more. During this time period the organization will get suffered owing to reduced productivity, declined market share, increased medical claims, and reduced profits. Hence, the degree of intensity of hazardousness of Coronavirus is very high or may be enormous humanly and financially.

\section{Corona's Impact on Employees}

Corona does have a serious impact on employees. There is no any employee working in any organization who is immune to Corona. Negatively and directly or indirectly all employees in all organizations in the world were affected, are being affected, and will be affected by Corona. It can affect managers as well as non-managers at all levels of the organization. There are employees who got caught by Corona. They suffered and some died and some got cured. There are employees who have not yet gotten caught by Corona. Are there employees out of danger? Definitely they are not. No one can predict who will get caught and who will not.

Health refers to general state of physical, mental, and emotional well-being; and a healthy person is free from illness, injury, or mental and emotional problems that impair normal human activity (Mathis and Jackson, 2011). It is possible to argue that employees who are healthy at present (not suffering from Corona) can become unhealthy owing to Corona. First it can happen mentally and then physically. Mental health is more related to human mind and emotions rather than to human body; and physical health is more related to human body rather than to human mind and emotions (Opatha, 2015).

It is possible to mention that fears can generate with an employee who is currently healthy having known that there is a disease called Corona. Here a fear means an unfavourable feeling the employee has when he or she thinks that he or she is in danger owing to the 
Corona. There are certain fears which will or may generate within a healthy employee (at least healthy in the sense he or she is not suffering currently from so called corona-he or she might be suffering from one or two or several of other types of diseases). These certain fears are:

1. Fear of getting affected by himself or herself (the employee is scared of the possibility that Corona catches him or her.)

2. Fear of possibility of getting quarantine (the employee is scared of the possibility of going through quarantine owing to the cases of infected employees or others)

3. Fear of getting stigmatized by the public and friends (the employee who got infected is scared of the possibility of stigmatization carried out by the public and friends.)

4. Fear of getting affected by his or her closely loved ones (the employee is scared of the possibility that Corona catches his or her spouse, children, parents, and other members of the family which may be nuclear or extended.)

5. Fear of getting affected by others (the employee is scared of the possibility that Corona catches other people who may be his or her superiors, peers, subordinates, internal customers, external customers, suppliers, and others.)

6. Fear of becoming a cause of spreading the epidemic (the employee, who was infected by the Corona, is scared of the possibility that he or she becomes a carrier of the epidemic.)

7. Fear of attending the work (the employee is required to come to work but he or she is scared of the fact that there is Corona pandemic.)

8. Fear of getting sanction/s (the employee becomes frightened of the possibility that his or her superior or the employer imposes disciplinary actions against him or her if not attended the work.)

9. Fear of peer pressure (the employee is afraid of the possibility that his or her peers criticize or work against him or her if he or she does become absent or tardy or disengaged.)

10. Fear of harsh customer response (the employee is scared of the possibility that customers who came to buy the goods or services react aggressively to absence, tardiness, disengagement, or slowness on the part of his or her behaviour.)

11. Fear of losing the job (the employee is scared of the possibility that the employer terminates his or her employment on disciplinary ground owing to acute absence, severe tardiness, disengagement, low performance, etc.)

12. Fear of continuity of business operations (the employee is scared of the possibility that the business affairs get dissolved, downsized or stopped and consequently his or her job gets lost or redundant or rewards including pay get cuts.)

13. Fear of inability of implementing plans developed (the employee is scared of the possibility that tentative business closure owing to Corona makes successful implementation of his or her work plans difficult or hard.)

14. Fear of inability of formulating new plans for better future (the employee is scared of the possibility that disturbances and distractions owing to Corona hinder or impair formulating new work plans for a better future for the organization as well as his or her career.) 
15. Fear of loss of pursuits of pleasure (the employee is scared of losing the pursuits of pleasure that are being adopted to enjoy the life owing to quarantine, curfew, tentative closures of relevant places and non-association of relevant individuals.)

It is argued that the employee will get one or two or several or all types of fears mentioned above and as a consequence he or she becomes stressful. This stress can be labeled as Stress By Corona (SBC). SBC is defined in the paper as what the employee experiences internally in response to Corona he or she finds difficult to deal with. It is also pointed out that the above mentioned fifteen fears may jointly affect to create stress within the employee. These fears can be identified as sub stressors which are additive. Refer to Figure 1.

Figure 1: Types of Employee Fear owing to Coronavirus

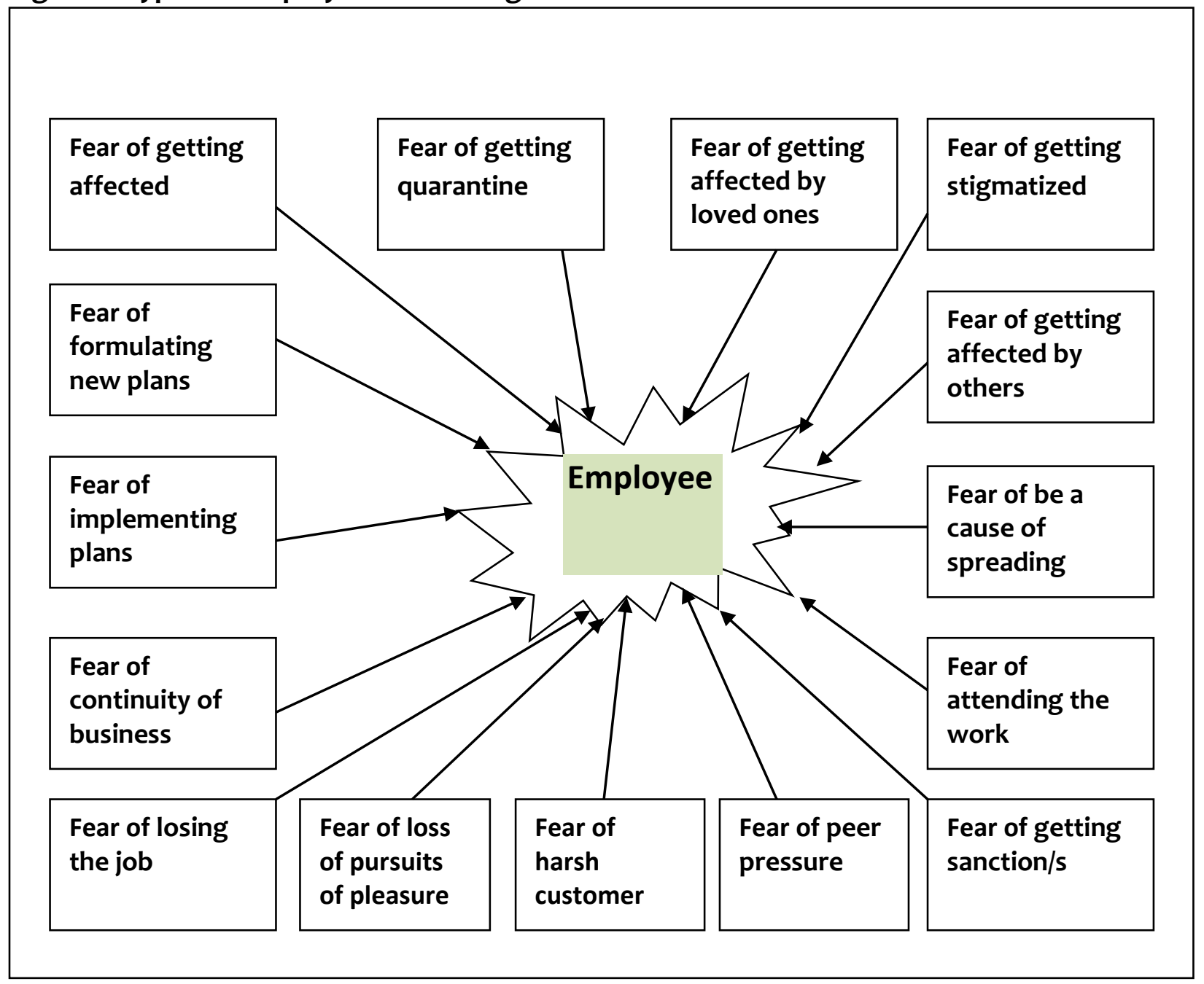

Unfortunately there may be employees in organizations who have already been suffering from stress which is the general term applied to the pressures people feel in life (Newstrom and Davis, 1997). What a disaster may happen if the normal stress gets combined with SBC! 
SBC may get combined by other workplace or job stressors (too much to do, insufficient authority, sudden change in work responsibilities, inadequate pay, lack of privacy, lack of time to perform entrusted duties, role ambiguity etc); personal stressors (weak financial position, conflict with spouse, conflict with a child, divorce, marital separation, sex problems, change in residence etc); and organizational stressors (poor communication, lack of feedback, job insecurity, organizational politics, lack of group cohesiveness, poor working conditions, poor supervision etc); and environmental stressors (technological change, economic uncertainties, political uncertainties, cultural changes or events (Opatha, 2010).

It has been observed in Sri Lanka that the government imposed curfew to curb with Corona during the crisis time (in the months March and April, 2020). The curfew (of course intermittent enforcements) which is an environmental stressor resulted in repercussions such as severe traffic, very long queues to buy foods and other goods and services, separations from loved ones and relatives, financial difficulties, higher cost of living due to inflated prices of goods and services, and quarrels with customers, sellers, health-related personnel and police personnel.

SBC and the normal stress do attacking mental health of the employee. Too much stress, also called strain, can lead to numerous negative physiological consequences (such as lowered immunity, increased risk of heart disease, type 2 diabetes, high blood pressure, and a range of musculoskeletal diseases), behavioural consequences (such as increased smoking and alcohol consumption, poor nutritional habits, increased substance abuse, lower task and contextual performance, higher absenteeism, higher turnover, and increased accident risk) as well as negative psychological ones (such as anxiety, lower emotional well-being, and lower job satisfaction) (Jackson, Schuler, Werner, 2013; Robbins, Judge, and Vohra, 2019).

Thus, a possible consequence of SBC coupled by the normal stress is job performance of the employee. Job performance is defined as the extent to which the employee has shown his or her traits, engaged in behaviors and produced results which are appropriate to task performance, and has engaged in citizenship performance and counterproductive performance during a particular period of time (Ramawickrama, Opatha, and Pushpakumari, 2017). When job performance gets hindered, organizational performance gets hindered as the summation of individual performance makes organizational performance or business performance (Hitt, Middlemist, and Mathis, 1979). Deteriorating business performance will have a direct negative impact on productivity at the national level. As Sri Lanka is striving to become an industrialized country in the future, concern on productivity is vital (Akuratiyagamage and Opatha, 2004).

When the stress of an employee (SBC coupled by the normal stress) continues for a prolong time, it is likely that the employee tends to get burnout. Prolonged exposure to stress results in burnout, and a burnout person is hypertensive, encounters chronic exhaustion, faces mental depression, and is cynical about everything (Aswathappa, 2017). Burnout is a gradually intensifying pattern of physical, psychological, and behavioural dysfunction that evolves in response to a continuous flow of stressor; and just as the engine of a car literally 
stops running without fuel and oil, a complete mental or physical breakdown can result from burnout (Reece, Brandt, and Howie, 2008).

If an employee becomes sick due to Corona, he or she has to suffer from all the bad consequences of the disease. If the spouse or a child or a parent of the employee becomes sick owing to Corona, the gravity of bad consequences is enormous. The organization will be in trouble to allocate works among, delegate authority to, and get things done through employees owing to increased absenteeism, tardiness, and employee turnover. Further it is possible that affected employees present grievances to the management that will have to take a lot of time, effort, and cost to settle them. A grievance means any discontent or dissatisfaction arising from a feeling or a belief of injustice felt by an employee or a group of employees in connection with the work environment (Opatha, 1994). For example, an employee can present a grievance if he or she is not granted a reasonable number of days of leave by the management (in order to do self-quarantine, health authority enforced quarantine, or reduce fatigue due to the continuous working etc). Another example: an employee has a concern about a peer who appears sick and complains it to the immediate superior. In case of non-speedy settlement of the grievances additional bad consequences include displacement effect (employee work time diverted from production tasks to grievance processing) and worker reaction effect (reduced employee effort as a reaction to the perceived unfair treatment) (Opatha and Ismail, 2001).

\section{Employees at Greater Risk}

Generally all types of employees are at risk because there is possibility of the attack of COVID-19 to any employee. Any employee is vulnerable to the virus infection. However, there are certain employees who are at greater risk. Health care employees who are at greater risk include doctors, nurses, medical technologists, therapists, laboratory technicians, patient attendants, and health inspection officers. These employees are 'first responder', that group of professionals who have initial contact with people affected by the disease (Holland, Sheehan, Donohue, Pyman, and Allen, 2012). These employees, specially relevant doctors, nurses and attendants are required to deal with disease outbreaks, to treat with the current infected patients, and minimize the number of mortalities. The psychological and physical impact of the disease is highest on these personnel. It is because of occupational exposure. Quarantine, personal infection and the risk of unknowingly transmitting infection to loved ones and colleagues represents a serious need to focus on the health and well-being of health care employees (Holland et al, 2012).

Security personnel (specially Army personnel in Sri Lanka have been) can be entrusted to manage quarantine of suspected people, and searching and directing people who are suspected for the infection but have not yet surrendered to follow the prescriptions made by the relevant health authorizes (such as Ministry of Health in Sri Lanka). Police personnel are utilized to enforce legal requirements such as curfew. Employees engaged in these two services are also at greater risk. 
Temporary and causal employees get more affected unfavourably compared with permanent employees of the organization. Compared with employees who are at the government sector, employees who are in the private sector tend to be at more risk. Major reason is that private sector organizations' affordability of employing their workforce gets impaired in a higher extent when there are government controlling actions such as curfew in the country.

\section{Discussion and Conclusion}

Coronavirus disease 2019, abbreviation of which is COVID 19, is an infectious disease which spreads primarily through droplets of saliva or discharge from the nose when an infected person coughs or sneezes. It is deadly and very expensive humanly and financially. It has potential to make the entire industrial and commercial workings of an area of a country, a whole country or many countries in the world paralyzed. COVID-19 has a tremendous negative impact on employees. 15 specific fears were identified and mentioned previously and they were identified as COVID-19 caused stressors and the resultant stress was labeled as Stress By Corona (SBC). The SBC combined with the normal stress may produce many bad consequences and even burnout which is highly harmful to the employee. Employees who are at greater risk are health care employees though generally all types of employees are at risk because there is possibility of the attack of COVID-19 to any employee.

Because of the fact that there is a deadly pandemic called COVID-19 all organizations irrespective of the size, industry, ownership, and location will have to face a serious challenge, i.e. how to protect employees from it. Employees are the lifeblood of the organization. All the types of the organizations or employers are required to take precautions to ensure employee protection from this pandemic. It does seem that WHO, public health authorities around the world, security forces (particularly in Sri Lanka) and other related personnel have been taking action to contain the COVID-19 outbreak. Long term success cannot be taken for granted, and therefore all sections of our society including businesses and employers - must play a role if we are to stop the spread of this disease (World Health Organization, 2020). Ensuring employee health through the prevention and control of the pandemic does ensure smooth running of the operations of the organization. Preventive actions will have to be taken before employees become infected and corrective actions will have to be taken after employees become infected. A discussion of these actions is beyond the objective of this research paper. Hence future conceptual and empirical research studies are needed to know the role of HRM in the prevention and control of COVID-19, and how organizations have actually encountered this danger. Empirical studies about successful as well as unsuccessful stories will be useful in this regard.

\section{References}

Akuratiyagamage, V.M. and Opatha, H.H.D.N.P. (2004), Grievances of middle managers: an empirical investigation into perceptions of commercial bank branch managers in Sri 
Lanka, Journal of Management Research, Faculty of Management Studies, University of Delhi, 4: 2, August, pp. 99-112.

Arulrajah, A.A. and Opatha, H.H.D.N.P. (2016), Analytical and Theoretical Perspectives on Green Human Resource Management: A Simplified Underpinning, International Business Research, Vol.9, No.12, pp. 153-164.

Aswathappa, K. (2017), Human Resource Management: Text and Cases, New Delhi: Tata McGraw-Hill Publishing Company Ltd.

Hitt, M.A., Middlemist, R.D., and Mathis, R.L. (1979), Effective Management, New York: West Publishing Company.

Holland, P., Sheehan, C., Donohue., Pyman, A., and Allen, B. (2012), Contemporary Issues and Challenges in HRM, $2^{\text {nd }}$ edi, Victoria: TILDE UNIVERSITY PRESS.

Jackson, S.E. and Schuler, R.S. (2003), Managing Human Resources, $8^{\text {th }}$ ed, Mason, OH: SOUTH-WESTERN CENGAGE Learning.

Jackson, S.E., Schuler, R.S., and Werner, S. (2012), Managing Human Resources, $11^{\text {th }}$ ed, Mason, OH: SOUTH-WESTERN CENGAGE Learning.

Mathis, R.L. and Jackson, T.H. (2011), Human Resource Management, $13^{\text {th }}$ ed, Mason, OH: SOUTH-WESTERN CENGAGE Learning.

Newstrom, J.W. and Davis, K. (1997), Organizational Behavior: Human Behavior at Work, New Delhi: Tata McGraw-Hill Publishing Company.

Noe, R.A., Hollenbeck, J.R., Gerhart, B., and Wright, P.M. (2007), Human Resource Management, New Delhi: Tata McGraw-Hill Publishing Company (Indian Print).

Opatha, H.H.D.N.P. (1994), Employee Grievance Settlement Procedure: A Case Study of Two Corporations, Management Review, Faculty of Management Studies and Commerce, University of Sri Jayewardenepura, Sri Lanka, Vol. 1, No.2, pp.53-60.

Opatha, H.H.D.N.P. (2009), Human Resource Management: Personnel, Colombo: Department of HRM, University of Sri Jayewardenepura.

Opatha, H.H.D.N.P. (2010), Personal Quality, Colombo: Department of HRM, University of Sri Jayewardenepura.

Opatha, H.H.D.N.P. (2015), Organizational Behaviour: The Human Side of Work, Colombo: Dept of HRM, University of Sri Jayewardenepura.

Opatha, H.H.D.N.P. (2019), Sustainable Human Resource Management: Expanding Horizons of HRM, Colombo: Department of HRM, University of Sri Jayewardenepura.

Opatha, H.H.D.N.P. $\left(2019^{2}\right)$, The Case for Teaching Human Resource Management in Management Education: 13 Common Reasons, Sri Lankan Journal of Human Resource Management, Vol. 9, No.2, pp. 15-38.

Opatha, H.H.D.N.P. and Ismail, Z. (2001), Towards Effective Worker Grievance Handling: Some Reflections, ANALISIS, Vol. 8, No. 1\&2, pp. 111-127.Schuler, R.S. and Youngblood, B.S.A. (1986), Effective Personnel Management, New York: West Publishing Company.

Orsi, M. and Santos, J. (2010), Probabilistic modelling of work-based disruptions and inputoutput analysis of independent ripple effects, Economic Systems Research, Vol. 22, No. 1, pp. 3-18.

Ramawickrama, J., Opatha, H.H.D.N.P., and Pushpakumari, M.D. (2017), A Synthesis towards the Construct of Job Performance, International Business Research, Vol. 10, No.10, pp. 66-81. 
Reece, B.L., Brandt, R., and Howie, K.F. (2008), Effective Human Relations, Ohio: SouthWestern CENGAGE Learning.

Robbins, S.P., Judge, T.A., and Vohra, N. (2019), Organizational Behavior, $18^{\text {th }}$ ed, Noida: Pearson.

Schuler, R.S. and Youngblood, B.S.A. (1986), Effective Personnel Management, $2^{\text {nd }}$ ed, New York: West Publishing Company.

Schwind, H, Das, H., Wagar, T., Fassina, N., and Bulmash, J. (2013), Canadian Human Resource Management, Toronto: McGraw-Hill Ryerson.

Staples, J. (2006), A new type of threat, Harvard Business Review, May, pp. 20-22.

The UC Davis Health Experts, accessed on 29/03/2020,

https://www.ucdavis.edu/coronavirus/what-is-coronavirus

University of Kansas, accessed on 29/03/2020, https://humanresources.ku.edu/coronavirus

Zhou, W. (2020), CORONAVIRUS PREVENTION HANDBOOK, New York: Skyhorse Publishing. World Health Organization (2020), Getting your workplace ready for COVID-19.

Worldometer, accessed on 18/04/2020,

https://www.worldometers.info/coronavirus/?utm campaign=homeAdUOA?Si 